\title{
A burla do gênero \\ Cacilda Becker, a Mary Stuart de Pirassununga
}

Heloisa Pontes

\section{Corpo, nome, marca, gênero}

U m dos domínios sociais e simbólicos mais intrigantes na circunscrição das relações de gênero diz respeito às conexõesentre corpo, marca, nomee renome. De acordo com a literatura antropológica disponível sobre 0 assunto, o processo de renomeação, quase sempre associado a situações rituais, é um dos marcadores sociais por excelência da aquisição de prestígio e de status nas sociedades não ocidentais. M arcados nos corpos, esses ritos sinalizam, sobretudo para os homens que deles participam, a transição para a maioridade e o avanço na "carreira" social. Sabemos, por exemplo, a partir da documentação deixada pelos viajantes e cronistas dos séculos XVI e XVII, e brilhantemente analisada por Florestan Fernandes, que, para os homens da sociedade Tupinambá, fazer a guerra, sacrificar ritualmente os prisioneiros, ganhar nome e renome eram a face e a contra-face de um mesmo fenômeno, e a forma suprema de "graduação" social. R itos de passagem e de renomeação, o sacrifício da vítima exprimia simbolicamente o reconhecimento da maturidade social do "matador". Graças a esse sacrifício ritual, completado pelo consumo canibalístico do corpo da vítima por parte de todos os membros da tribo, com exceção do "mata dor", este adquiria uma "força" ou "virtude vivificadora" que não possuía antes, ganhava novos "nomes", tinha acesso às mulheres, ao casamento, à 
paternidade, munia-se de atributos religiosos, assegurava a sua vida futura (Fernandes, 1970). N essa sociedade de guerreiros, o "inimigo" era a condição essencial para a sua produção e reprodução. $N$ as pal avras deV iveiros de C astro, "sem inimigo não há a pessoa, feixe de nomes, corpo laboriosamente coberto de incisões comemorativas [...]. Sem mortos al heios não há, literalmente, vivos" (1986, p. 660).

Essa conexão entre corpo, marca e gênero tem suscitado interpretações distintas a respeito dos significados envolvidos nos rituais que a enfeixam: ritos de passagem, na acepção de Van G ennep, ou de instituição, como mostra B ourdieu. A ssentados na exclusão e na violência simbólica, eles visam a separar, segundo o sociólogo francês, "aqueles que já passaram por eles daqueles que ainda não o fizeram e, assim, instituir uma diferença duradoura entre os que foram e os que não foram afetados" (Bourdieu, 1996a, p. 97). N o caso, por exemplo, do ritual cabila de circuncisão, ele separa o rapaz das mulheres e do mundo feminino (vale dizer, separa-o da "mãe e de tudo o que a ela se associa, o úmido, o verde, o cru, a primavera, o leite, 0 insípido etc." ), ao mesmo tempo em que "converte o mais efeminado dos homens num homem na plena acepção da condição de homem, separado por uma diferença de natureza, de essência, mesmo da mais masculina, da maior e da mais forte das mulheres" (I dem, p. 99).

Há algo nessa correlação entre exclusão, marcas no corpo e gênero, sancionada pelos ritos e assegurada pelos processos de renomeação, que ultrapassa o escopo dos mecanismos societários analisados pela literatura antropológica. O sestudos produzidos no âmbito da história social das artes e da sociologia da cultura têm trazido contribuições fundamentais para repensarmosa equação entre nome, status e prestígio a partir de sua articulação com o problema da autoria e da autoridade. Tomemos, a título de exemplo, a notável análise do historiador da arte $M$ ichael $B$ axandall a respeito de uma transformação capital, ocorrida ao longo do século XV, na apreciação social e estética da pintura italiana, ligada à "consciência cada vez mais distinta quanto à individualidade do artista" (Baxandall 1991, p. 31). A té 1410,0 elemento mais valorizado na pintura, por parte do cliente que a comprava, ligava se ao tipo de material utilizado. $\mathrm{N}$ a hierarquia da época, o azul cobalto e os pigmentos preciosos ocupavam o topo da escala. Q uanto mais um quadro era pintado com esses materiais, maior era o seu valor estético e monetário. No decorrer do século, porém, observa-se uma diminuição do consumo do ouro e do ultramarino e sua substituição "pelo consumo igualmente ostensivo de uma outra coisa - a habilidade do pin- 
tor" (Idem, p. 26). N esse processo, o problema da autoria e do nome do pintor começa a ganhar vulto justamente por meio da perícia e da habilidade em pintar os corpos dos retratados, fossem eles os anjos, as madonas ou as figuras alegóricas ${ }^{1}$.

A partir de então, a questão da autoria, da atribuição e da autoridade estética se firma e dá sinais claros de que se instalara de forma definitiva no âmbito da pintura. Habilidade no manejo dos pincéis, destreza nos gêneros mais prezados, exposição prolongada no aprendizado das técnicas e no estudo do modelo vivo, tudo isso compunha o rol de exigências, nos séculos XVIII e XIX, para que um aprendiz da pintura pudesse um dia ter o seu nome conhecido e reconhecido. Como mostram estudos recentes voltados para a análise da inflexão das dimensões de gênero na história da arte desse período, o desenho a partir de um modelo vivo, sendo a etapa que separava o estudante inicial do estudante avançado, tinha um significado simbólico decisivo na conformação da carreira de um pintor.

Excluídas do estudo do modelo vivo, as pintoras da época não obtiveram, nem de longe, o mesmo reconhecimento dos seus pares, clientes ou mecenas. Se, nesse período, o nome de um pintor de prestígio estava intimamente associado à sua destreza na pintura histórica e à sua habilidade de retratar os corpos, claramente diferenciados entre masculinos e femininos, não é de estranhar que as mulheres estivessem quase ausentes desse sistema de reputações. Como em todos os domínios da produção cultural e intelectual (segundo vários dos estudos desenvolvidos pela sociologia e pela história da cultura²) e, especialmente, no campo da pintura, "há questões aparentemente exteriores ao mundo da estética" que, como mostra Ana Paula Simioni,

\section{[...] são fundamentais para que se compreenda a gênese dos valores estéticos e a exclusão que eles operam. A questão da participação das mulheres no mundo da pintura acadêmica permite que esse sistema, auto-intitulado imune às pressões ex- ternas (concebendo a diferença entre os artistas como assentada em dons, por exem- plo), se revele eivado de constrangimentose relações de poder (2002, p. 147).}

\section{Nome, renome, autoridade intelectual e cultural}

Tardia no caso da pintura, a questão do nome próprio para as mulheres, e do renome a ele associado, também se deu de forma complexa e tortuosa no campo intelectual. Basta pensarmos, nesse sentido, no círculo
1. Se 0 ateliê do pintor não eraainda completamente individua lizado, na medida em que conviviam num mesmo espaço o mes tre e seus assistentes, torna se cada vez mais clara a distinção entre eles. O scontratos ana lisados por Baxandall (1991) são inequívocos nessa direção. Ao encomendar uma pintu$\mathrm{ra}$, os grandes clientes da época estipulavam claramente uma distinção entre o que deveriaser pintado pelomes tre do ateliêe o queseria executado por seus assistentes $C$ abiam aos primeiros as figuras mais valorizadas e as partes "nobres" do corpo, como os rostos, as mãos e tudo que envolvesse a expressão dos sentimentose dos movimentos.

2. Ver, entre outros, os seguintes trabalhos: Baxandall (1991); C larck (1986); A rruda (2001); Gluck (1985); Bender (1987); Bourdieu (1984; 1996b); Elias (1985, 1995); Schorske (1993); W illiams (1982, 1989); Miceli (1997). 
3.Para um detalhamento maior dasociologia estética praticada por Gilda de M ello e Souza, ver Pontes (2004).

4. Situação não muito diferente, ainda que com conteúdos distintos, daquela vivida na sociedade $X$ avante, em que um homem, como mostra MayburyLewis, "deve ter, teoricamente, no mínimo quatro nomes", enquanto as mulheres "podem crescer sem nome" (1984, p. 113). de intelectuais, escritores e críticos do Bloomsbury G roup, na Inglaterra, e do Grupo C lima, em São Paulo, cujos centros de sociabilidade inicial foram, respectivamente, a U niversidade de Cambridge e a Faculdade de Filosofia da U niversidade de São Paulo. Aqui como lá, como mostrei em outro trabalho (Pontes, 1998), as mulheres que integraram esses grupos ocuparam uma posição secundária e foram relativamente excluídas ou se auto-excluíram (o que dá no mesmo, pois representa a forma cabal da internalização psicológica de uma exclusão social) dos espaços mais amplos de produção intelectual e cultural, marcadamente masculinos, da época. A flagrante exceção da escritoraVirgíniaWoolf (no caso do Bloomsbury) e de G ilda de M ello e Souza (a única mulher do Grupo C lima que conquistou nome próprio, em razão da sua trajetória acadêmica e dos traba Ihos que produziu nas áreas de sociologia e estética ${ }^{3}$ ) apenas confirma a assimetria das relações de gênero no interior desses círculos.

O utro exemplo nessa direção é dado pela história da antropologia brasileira. Ao tentar reconstruir a passagem pelo Brasil de Dina LéviStrauss - que em 1938 chegou a São Paulo, junto com o seu então jovem e quase desconhecido marido, 0 antropólogo C laude Lévi-Strauss-, M ariza C orrêa defrontou-se com uma situação inquietante. D urante quatro anos procurou por D ina, " que, se não era uma celebridade na história da antropologia, também não era uma desconhecida" (C orrêa, 1995, p. 109). Decepcionada com o resultado dessa busca, em que D ina ora aparecia como uma referência secundária, ora desaparecia sob a rubrica" casal Lévi-Strauss", ora, ainda, tornava se apenas a "mulher de Lévi-Strauss" , M ariza deu "tratos à bola" e enveredou pela questão da "notoriedade retrospectiva" , isto é, pelo modo "como o renome adquirido a partir de um certo momento pode iluminar a vida inteira de um personagem" e ofuscar a de outro.

R efletindo sobre a "notoriedade retrospectiva" de Lévi-Strauss e o "esquecimento" de Dina, a autora começou a se perguntar o que teria sido feito das outras pesquisadoras estrangeiras naquele momento de implantação da antropologia no país. "Todas elas adotaram o nome do marido ao casar, a ponto de ser muito difícil redescobri-las com seus nome próprio, mesmo quando descasadas, como no caso de D ina" (I dem, p. 113)4.

Diante desse e de outros exemplos, cabe a pergunta: o que significa um nome e quais são as conexões entre nome, gênero e corpo? M ariza C orrêa abre pistas instigantes para começarmos a responder essa questão. A seu ver, o nome não seria outra coisa que o renome, "no duplo sentido de nome famoso e de segundo nome, no caso das mulheres" (Corrêa, 
2003, p. 22), que, com freqüência, 0 adquirem ao casar. R enomeadas, as mulheres tornam-se "esposas".

Se isso se aplica às mulheres de um modo geral, como entender os casosque contrariam, se não a regra, ao menosa sua abrangência explicativa? U m exemplo vigoroso nessa direção é dado pela história do teatro brasileiro. $M$ ais do que em qualquer outra esfera da produção cultural e intelectual brasileira até os anos de 1950, no teatro as mulheres conquistaram mais cedo e de forma eloqüente o nome próprio e o renome a ele associado. Sendo um dos bens simbólicos mais prezados nessas efferas, como mostrou Bourdieu (1984; 1975), o "nome próprio" funciona como uma marca ou uma "grife" que, em virtude desses processos intrigantes de alquimia social, tem o efeito "mágico" de produzir uma "curiosa contaminação de prestígio" paratudo e todosque gravitam ao seu redor ". "Glória de empréstimo", diria outro arguto analista da vida em sociedade, no caso o nosso escritor $M$ achado de Assis.

N o caso do teatro brasileiro, o prestígio decorrente dessa "assinatura" é inseparável dos empreendimentos ligados aos movimentos de implantação e consolidação da sua dimensão propriamente moderna. Tanto nos gruposamadorescriadosna década de 1940 - como o GUT (G rupo U niversitário deTeatro), dirigido por D écio de Almeida Prado; 0 GTE (Grupo de Teatro Experimental), dirigido por Alfredo M esquita; o Teatro do Estudante, criado e dirigido inicialmente pelo diplomata Paschoal $\mathrm{C}$ arlos M agno; e 0 sC omediantes, responsáveis pela encenação de $V$ estido denoiva, de $\mathrm{N}$ elson R odrigues, tida por todose desde a sua estréia no R io de Janeiro, em 1943, sob a direção de Ziembinski, como o marco zero do moderno teatro brasileiro ${ }^{6}$ - quanto nos projetos que implicaram a profissionalização da atividade teatral, como o T BC (Teatro Brasileiro de Comédia), símbolo do teatro paulista na virada da década de 1940 e referência obrigatória nos anos de 1950, ou nas várias companhias que surgiram no período, as atrizes tiveram uma atuação e uma projeção excepcional, só al cançadas na música popular, em que se destacaram como cantoras e ga nharam uma popularidade expressiva. M as o prestígio que as últimas desfrutaram no período não parece se igualar ao das atrizes que atuaram no movimento de implantação e sedimentação dos princípios estéticos e das rotinas de trabalho do teatro moderno.

Alinhado à produção cultural erudita, esse tipo de teatro não perdeu a ligação com a tradição do teatro popular ou de feitio mais tradicional, apesar da origem social diversa de seus integrantes, recrutados predomi-
5. Para um desenvolvimento dessa idéia em outro contexto, ver Pontes (2003).

6. Sobre Os Comediantes, ver a edição monográfica sobre 0 grupo, D ionysos, 22 (1975). Sobre o impacto da direção de Ziembinski em Vestido de noiva, ver M ichaski (1995). Sobre N elson $\mathrm{R}$ odrigues, ver $\mathrm{C}$ astro (1992) e Magaldi (1987). Para uma visão geral do teatro brasileiro no período, conferir Prado (1988). 
7. Eliminado no teatro moderno, o ponto era uma presença obrigatória no teatro popular, no qual atores e atrizes, submetidos a outro ritmo e concepção de trabalho, não tinham tempo nem se preocupavam em decorar suas falas. Contavam, para tanto, com o ponto, que, escondido da platéia, soprava asfalas das personagens para os atores. 0 utra característica desse teatro eram os "cacos", as falas e deixas improvisadas na hora do espetáculo que nada tinham a ver com o texto original. A atriz Dercy Gonçalves, comediante de mão cheia, senotabilizou junto ao público por esse tipo de procedimento.

8. Sugestiva nessa direção éa reflexão de Décio de A Imeida Prado a respeito do sucesso alcançado pelo ator Procópio Ferreira na primeira metade do século passado. Em suas palavras," por quase três décadas ele reinara inconteste - 0 ator mais engraçado de um teatro que se queria unicamente cômico. R ecebera indusive a mais alta homenagem prestada aos nantemente "junto a camadas sociais diferentes daquelas que desde 0 século XIX geravam os elencos nacionais, em geral de origem bastante humilde" (Brandão, 2002, p. 72). Sem perder de vista as diferenças considerá veisentre um e outro - evidenciadas sobretudo pelo trabal ho dos diretores e dos cenógrafos, pela escolha do repertório, pelas exigências do ensaio prolongado, pela eliminação do ponto e dos $\operatorname{cacos}^{7}$-, a presença da primeira atriz continuou a ser central na montagem e no sucesso dos empreendimentos teatrais modernos. Prova disso são as companhias que se formaram a partir de conflitos profissionais ou amorosos ocorridos entre os integrantes do elenco do Teatro Brasileiro de Comédia, como as de M adalena $\mathrm{N}$ icol e R uggero Jacobbi, $\mathrm{N}$ ydia Lícia e Sérgio $\mathrm{C}$ ardoso,T ônia C arrero, A dolfo C eli e Paulo A utran, $C$ acilda Becker e Walmor C hagas.

Domínio instigante para adensarmos a etnografia das relações de gênero e suas inflexões na estrutura e na dinâmica dos campos de produção cultural, o caso do teatro e a notoriedade de várias de suas atrizes são tema privilegiado para uma análise mais detida das conexões entre corpo, gênero, nome e convenções. D e um lado porque, diferentemente do que ocorre em outros espaços profissionais, a ligação entre esses domínios adquire no teatro contornos singulares 8 .

Pensemos, por exemplo e de forma contrastiva, no caso das modelos que "emprestam" o seu corpo para as grifes da alta costura, para a indústria do cosmético ou para as "marcas" de consumo de massa com toques de exclusividade de elite. $N$ uma posição intermediária entre as divas do cinema e as atrizes do teatro, as modelos vêm ganhando um espaço de projeção e reconhecimento impensáveis em tempos anteriores. Poucas mulheres foram tão fotografadas no mundo quando a modelo brasileira, com circulação internacional, Gisele Bündchen.

Se o campo da moda, como o do teatro, é marcado por convenções específicas, ocorre que nele e para as modelos a ligação entre nome, renome e corpo está "condenada" de início às mudanças inelutáveis do enveIhecimento corporal. Famosas, sim, mas por um tempo curto e delimitado. $\mathrm{N} o$ caso do teatro, não. C laro que a passagem do tempo e o envelhecimento associado criam constrangimentos específicos para as atrizes, distintos daqueles enfrentados pelos atores. $\mathrm{N}$ em todos os papéis podem ser representados por todos, não só em virtude do "talento" de cada um, mas também por injunções "extra-artísticas". U ma atriz de 70 anos não pode, em princípio, fazer o papel de uma mocinha de 20 , tampouco esta pode representar a maturidade física, psicológica ou emocional da primeira. $M$ as 
existe um espaço de negociação de sentidos, social e culturalmente compartilhado entre os profissionais do teatro e o público, que torna possível e em vários casos desejável - "burlar" os constrangimentosimpostos pelo tempo ${ }^{9}$ ou pela natureza imaginária do gênero. U ma grande atriz, diferentemente de uma modelo famosa, "sobrevive" à idade e às marcas deixadas pelo tempo em seu corpo. U m dos exemplos mais eloqüentes nesse sentido é, sem dúvida, o de Fernanda M ontenegro.

Em relação ao gênero, um exemplo fascinante nessa direção é dado pelos cantores castrados na Itália do século X V II. C astrados antes de atingirem a puberdade, com o objetivo de preservar o registro agudo de suas vozes, que poderiam assim atingir as notas musicais mais altas, eles eram recrutados preferencialmente entre as camadas empobrecidas da popula ção, ou em vias de, para cantarem nos corais da I greja e nos espetáculos de ópera, que não admitiam a presença de mulheres. Donos de uma voz considerada "sublime", atingindo um registro só alcançado pelas sopra nos, faziam os papéis femininos mais requisitados pelos espetáculos de ópera da época. N aquele contexto, "soprano" significava, segundo R osselli, "mais agudo ou mais elevado, uma noção levada a sério por uma sociedade que era ao mesmo tempo guiada por uma concepção estrita de hierarquia e tendente a infundir ordem hierárquica em formas captadas pelos sentidos" (1992, p. 34).

Toda arte - e o teatro em especial - é, segundo A natol R osenfeld, "liga da a convenções, já tornadas inconscientes e quase despercebidas, e nenhuma arte existe que queira imitar simplesmente a vida" (1993, p. 79)10. Se assim o é, temos que nos livrar de vez de qualquer concepção naturalizante ou essencialista no tocante às relações de gênero e às razões pressupostas para explicar o destaque das atrizes no campo do teatro brasileiro. A idéia de que elasteriam conquistado essa posição em razão de uma suposta divisão natural de "papéis" necessária à realização da arte da dramaturgia, ou, dito de outra forma, que é "natural" que assim o seja, uma vez que tratando da vida, mesmo que pelo prisma das convenções teatrais, o espetáculo exige a princípio a participação de homens e de mulheres, não se sustenta empírica e historicamente. B asta lembrar, com a ajuda de A natol R osenfeld, que o "teatro grego não admitia a presença de atrizes" (I dem, p. 85). C om o auxílio das máscaras, os atores gregos podiam desempenhar todos os papéis. Tempos depois, durante grande parte da Idade M édia, existiu, segundo R osenfeld, " uma corrente teatral cômica, ao lado da religiosa dosmistérios, de caráter carnaval esco, freqüentemente pornográfica, seus grandes homens pela opinião pública brasileira - perdera o sobrenome. Q uando se falava em Procópio, ninguém tinha dúvida de que se tratava naturalmente de Procópio Ferreira" (1993, p. 43, grifos meus).

9. Para uma discussão densa dos constrangimentos sociais e culturais do envelhecimento na sociedade contemporânea, ver D ebert (1999).

10. Para uma discussão estimulante sobre a questão dasconvenções no plano pictórico, consultar o ensaio briIhante do historiador C arlo Ginzburg (1989). A idéia de que a representação, no plano pictórico, supõe a intervenção de uma tradição e de um esquema ("essa conjuntura inicial destinada a ser continuamente corrigida e modificada", segundo Ginzburg [p.86]) traz consigo duas implicações analíticas. Em primeiro lugar, a pressuposição formulada porW ölfflin, de que "todos os quadros devem maisa outros quadros do que à observação direta da realidade" (apud G inzburg, p. 86), ou, nas pa- 
lavras de Gombrich, de que " 0 artista pode copiar a realidade referindo-se unicamenteaoutros quadros". Em segundo lugar, a certeza deque"aleitura de uma imagem nuncaéóbvia, namedidaem queo observador se depara semprecom umamensagem ambígua [...]. E a ambigüidade, segundo Gombrich,éachave de todo o problemadaleitura da imagem" (apud Ginzburg, p. 84). em [que todos] os papéis femininos eram desempenhados por homens" (Idem, p. 89).

Por tudo isso, o caso do teatro, ao oferecer um dos exemplos mais bemsucedidos da importância das mulheres num campo de produção cultural, abre novas pistas para a análise das relações de gênero em sua interface com a questão do corpo e das convenções sociais e artísticas, conforme tentarei mostrar a seguir a partir da apreensão de al gumas dimensões significativas da carreira de $\mathrm{C}$ acilda Becker.

\section{Uma pessoa e um teatro: Cacilda Becker}

M uito já foi dito e escrito sobre C acilda Becker (1921-1969). R eferência obrigatória nos estudos acadêmicos e registros jornalísticos da história do teatro brasileiro nos anos de 1940 a 1970, ela comparece, nas últimas três décadas, como título dos seguintes livros: $U$ ma atriz: $C$ adilda B ecker (1983), C aailda B ecker: o teatro e suas chamas (1995) e C aailda B ecker: fúria santa (2002). 0 s dois primeiros foram redigidos ou organizados por mulheres diretamente ligadas à cena teatral, quer na condição de intérpretes e estudiosas de sua história, como $\mathrm{N}$ anci Fernandes e $\mathrm{M}$ ariaT hereza Vargas, quer de dramaturga ocasional, como R enata Pallotini. 0 último, que pretende ser uma biografia exaustiva, foi escrito por um jornalista que não a conheceu, LuisA ndré do Prado. Sem contar as avaliações que recebeu em vida dos encenadores que a dirigiram, dos admiradores do seu trabalho e dos críticos de teatro que acompanharam a sua bem-sucedida trajetória artística, al gumas delas notáveis pela capacidade interpretativa, como as de Sábato M agaldi e especialmente as de D écio de Almeida Prado - cuja carreira como crítico de teatro foi simultânea à de $C$ acilda como atriz. A mbosse iniciaram no teatro em 1941. Ela no R io de Janeiro, no papel de Zizi, em 3200 metros de altura, comédia de Julien Luchaire encenada pelo grupo Teatro do Estudante do Brasil. Ele em São Paulo, como crítico amador de teatro da revista $\mathrm{C}$ lima, antes de sua profissionalização, a partir de 1946, no jornal 0 E stado de $S$. Paulo.

Se 0 ano de ingresso no mundo do teatro foi o mesmo, completamente distintas, no entanto, eram as concepções de ambos sobre as artes cênicas. Ligado especialmente ao que se passava na cena teatral francesa e empenhado em construir, aqui, as condições necessárias para a implantação do teatro moderno brasileiro, em 1941 Décio estava a anos-luz de distância de $C$ acilda nesse domínio. D estituída de quase todo tipo de capital (social, 


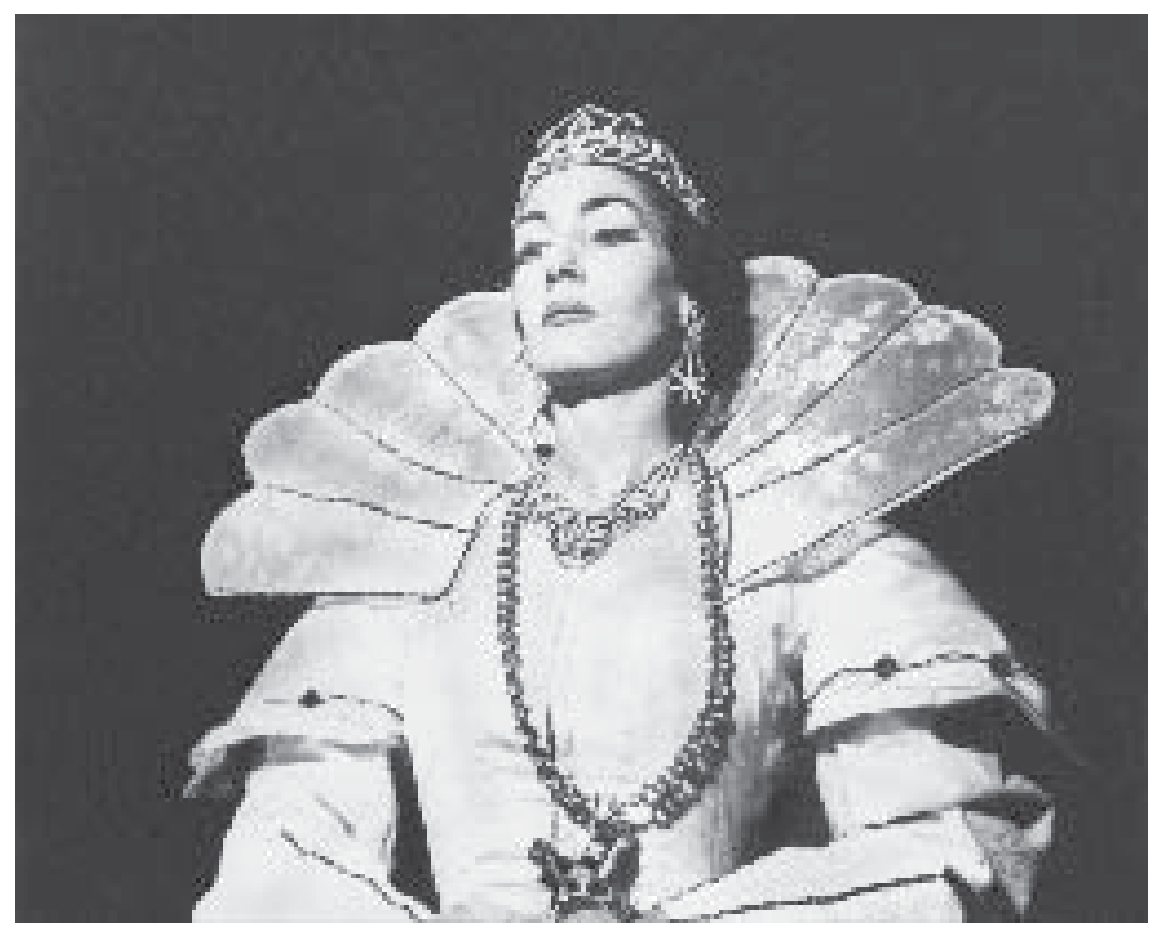

Cacilda Becker como Mary Stuart, no TBC, setembro de 1955. Acervo Fredi Kleemann, Arquivo Multimeios do Centro Cultural de São Paulo. Foto cedida pela editora Geração Editorial.

econômico e cultural), e vendo esvair o sonho juvenil de ser dançarina, C acilda mudou-se de Santos para o R io de Janeiro em 1941, para tentar a vida profissional como atriz. Sua familiaridade com o teatro, entretanto, era nula: até então, nunca tinha visto um espetáculo e, quando subiu ao palco, foi para dar continuidade a uma rotina de trabalho que vinha emperrando o ajuste do teatro brasileiro às transformações em curso na cena teatral internacional.

Ela, que nos seus melhores momentos como atriz viria a ser "uma pura chama ardendo diante de nós" (Prado, 1969) - tal o impacto de várias de suas atuações no palco - , iniciara-se na contramão das concepções teatrais de $D$ écio. A lembrança desse começo dá uma idéia precisa da distância que os separava. Q uando C acilda ingressou na vida profissional,

[...] os atores não recebiam o texto da peça, mas apenas folhas soltas de papel com as fal as que teriam de dizer em cena, após uma deixa de outra personagem. N este caso, todo o aspecto do relacionamento das personagens era sempre um mistério só desvendado em cena. $\mathrm{N}$ a época, normalmente, montavam-se peças de quinze em quinze dias. 0 satores contavam sempre com o ponto. I sso sempre me pareceu 
11. D efinido como "uma forma de associação baseada na es tima profissional e no respeito recíproco", 0 C artel garantia a cada um dos seus quatro integrantes a" conservação plena da liberdade artística" e o direito de permanecerem senhores de suas escolhas. Ao lado do combate à mediocridade, da defesa apaixonada de um teatro puro, do tratamento dasques tões de ordem profissional, elescomprometiam-se a se solidarizar "em todos os assuntos em que os interesses profissionaise morais de cada um delesestivessem em jogo" (cf. Jouvet et al., 1997, p. 188).

12. Sobre a influência de Jouvet na formação teatral de Décio, ver Bernstein (1995); Pontes (2000); M agaldi (2001, pp. ix-xv). Para um detalhamento maior da trajetória de Décio como crítico e historiador do teatro, ver Faria, A rêas e Aguiar (1997). um absurdo, mas quem era eu naquela época [...] para reagir contra a norma aceita por todo o teatro? (trecho de depoimento de C acilda Becker, cf. Vargas e Fernandes, 1995, p. 34).

$\mathrm{O}$ u, melhor, por quase todo o teatro. Isto é, pela maioria dos integrantes do teatro profissional. M as não pelosamadores (atores, diretores e críticos, como D écio, por exemplo) que estavam em vias de produzir, no país, uma transformação capital no modo de fazer e conceber as artes cênicas.

Em 1943, os caminhos de Décio e de C acilda cruzaram-se pela primeira vez. Temporariamente instalada em São Paulo, ela foi dirigida por D écio na peça A uto da barca do inferno, de Gil Vicente, encenada pelo Grupo U niversitário deTeatro. N o papel da alcoviteira BrígidaVaz, que criava as meninas para os cônegos da Sé, C acilda compusera a personagem praticamente sozinha. N as palavras de D écio, ela "enegrecera as mãos, desfigurara o rosto com uns traços que me pareceram exageradíssimos, mas que funcionavam perfeitamente à distância, modificara a voz, modulara a palavra como que acariciando melodicamente cada sílaba" (1993b, p. 141). N essa montagem, Décio recebeu de Cacilda duas lições:

[...] primeiro, que a vaidade do artista, a legítima vaidade do artista, que em C acilda já era muito grande e aumentaria com a idade, nada tem a ver com 0 narcisismo pessoal, com o desejo de se mostrar bela e atraente. $A$ beleza que ela perseguia era de outra natureza. Segundo, que a arte de representar exige tanta imaginação criadora quanto a de escrever. 0 dramaturgo fornece as palavras. 0 resto, que na hora da representação é quase tudo, compete ao ator (Idem, ibidem).

Essa avaliação apaixonada dá bem o tamanho do impacto que C acilda exerceu sobre D écio naquele momento - sobretudo se não perdermos de vista que, adepto dos princípios estéticos defendidos pelo grupo do Cartel (criado em 1927, em Paris, por Louis Jouvet, C harles D ullin, George Pitoëff e Gaston Baty) ${ }^{11}$, D écio estava empenhado em fazer valer aqui a hierarquia de valores que recebera dos ensinamentos de Jouvet, os quais concediam ao texto o lugar central, relegando a um segundo plano, ainda que fundamental, os atores e até mesmo os diretores ${ }^{12}$. U m entre os muitos impactos que $C$ acilda produziria em $D$ écio e que ele deixaria registrado dali para frente, não mais como diretor amador e sim como crítico de teatro de 0 Estado de S. Paulo, ao longo dos 22 anos que escreveu para 
esse jornal. $\mathrm{N}$ o decorrer desse tempo, ele foi de longe o crítico que meIhor rastreou, acompanhou e avaliou os 28 anos de carreira da atriz.

C acilda, que de início nada sabia sobre teatro e que, quando começou a se enfronhar no meio, não se envergonharia de preferir as peças "gostosinhas" às de qualidade literária indiscutível, encontrou em D écio o seu intérprete mais qualificado, a um só tempo generoso e exigente, graças às condições favoráveis que, permitindo a renovação da cena teatral paulista nos anos de 1940, possibilitaram também o encontro dos dois: de um lado, em virtude da atuação dos grupos amadores, como o G rupo Experimental de Teatro e o Grupo U niversitário de Teatro (no qual, como vimos, C acilda foi dirigida por D écio), e, de outro, pela criação, em 1948, do Teatro Brasileiro de Comédia ${ }^{13}$. C apitaneados por Franco Zampari, secundados pelo apoio recebido do jornal 0 E stado de S. Paulo e aplaudidos por um público de extração majoritariamente burguesa, atores, encenadores, críticos, empresários, professores de arte dramática e cenógrafos vinculados ao T BC formavam, segundo D écio, um

[...] esquadrão cerrado e aguerrido que em poucos anossubverteu todo o quadro do teatro brasileiro, imprimindo-Ihe novas práticas e novos princípios. 0 sespetáculos anteriores organizavam-se por assim dizer das partes para o todo. C ada ator interpretava a seu modo o seu papel e dá resultava o conjunto - quando resultava. Invertemos a precedência. Primeiro, a visão total, nascida de uma só inteligênciae de uma só sensibilidade. Depois, a obediente execução coletiva. A figura do encenador, encarregada de conferir unidade ao espetáculo, fazia assim a sua entrada triunfal em palcos brasileiros, cinqüenta anos após ter sido inventada na Europa (1993a, pp. 95-96).

D écio foi, por assim dizer, o crítico de plantão dessa bem-sucedida iniciativa empresarial e artística. E C acilda, a sua primeira atriz, antes da eclosão dos conflitos que culminaram com o seu afastamento em 1957, para fundar a própria companhia. Sucesso de público e de crítica, superando-se a cada novo papel, sua ascensão como atriz, verdadeiramente vertiginosa, mimetizava o crescente prestígio do T BC junto ao público paulista nos seus primeiros anos de existência. Conforme ela crescia como atriz, D écio firmava-se como a "consciência privilegiada" da renovação da cena teatral paulista, na feliz expressão de Sábato M agaldi (2002, p. ix). A cada nova montagem do T BC e a cada nova representação de $C$ acilda, os elogios multiplicavam- se em sua coluna não assinada, sob a forma de
13.Para uma visão mais abrangente das transformações que se estavam produzindo no teatro em São Paulo naépoca, ver Guzik (1986); D ionysos (set. 1980); Lessa (2002).Ver ainda Galvão (1981) e, especialmente,A rruda (2001), para uma análise densa das mudanças culturais que tiveram lugar em São Paulo nas décadas de 1940 e 1950. 
notas da redação (como era costume naquela época) em 0 E stado de $S$. Paulo.Vindas de alguém como ele - universitário de formação, sintoniza do com o que de mais relevante estava sendo produzido na cena teatral em âmbito internacional, em luta aberta contra a crítica impressionista que pautara a apreensão anterior do teatro brasileiro, empenhado em produzir uma crítica exaustiva e compreensiva de cada espetáculo em pauta, iniciada com uma avaliação do texto e do trabalho do diretor, passando pelo dos atores e dos cenógrafos e encerrando-se com uma visão geral do espetáculo -, tais avaliações entusiasmadas nada têm dos elogios "bombons", tão comuns nas críticas impressionistas.

Emitidos por Décio e aplicados a Cacilda, os elogios vêm sempre acompanhados por uma observação pormenorizada do trabalho da atriz, que estava longe de ser uma principiante quando se integrou ao T BC, em 1948. Durante os sete anos anteriores, divididos entre $\mathrm{R}$ io de Janeiro e São Paulo, ela atuara como atriz profissional em companhias de feitio tradicional, como as de R aul R oulien e de Bibi Ferreira, e em al guns dos gruposque mais contribuíram para a renovação do teatro brasileiro, como O s C omediantes, o Teatro do Estudante do Brasil e o Grupo U niversitá rio de Teatro. $N$ esses sete primeiros anos de vida profissional, encenara 28 peças, protagonizara papéis muito diferentes e trabalhara com atores, atrizes e diretores de distintas procedências e filiações estéticas. R eunira nessa experiência uma bagagem diversificada que continha a um só tempo 0 melhor e o pior da rotina de trabalho no teatro na época: velhos modos de fazer e conceber as artes do espetáculo misturados àqueles mais modernos, que despontaram na década de 1940. Ao ingressar no T BC, com 27 anos de idade, ela trazia, assim, 0 "antes e 0 depois" que dividiu a história do teatro brasileiro. $M$ as, como sua formação cultural era ainda muito rala, apesar da garra, da obstinação, da disciplina e do talento já demonstrados, foi só no TC B que sua carreira deslanchou de fato, como resultado de um conjunto de circunstâncias muito precisas, no interior das quais se mesclam condicionantes de ordem biográfica, social, institucional e artística. Sobre isso falaremos depois.

Por hora, vale reter al gumas das observações de D écio sobre o desempenho de $C$ acilda no decorrer dos nove anos em que permaneceu no T BC, de 1948 a 1957. N esse período, ela atuou em 23 peças e fez alguns dos papéis que a projetaram como a maior atriz brasileira da época, como Inês (em Entre quatro paredes, de Sartre, direção de Adolfo Celi), Alma W inemiller (em 0 anjo de pedra, deTennesseeW illiams, direção de Luciano 
Salce), Pega-Fogo (em P ega-F ogo, de JulesR enard, direção de Z iembinski) e $M$ ary Stuart (drama de Schiller, direção de Ziembinski). Essas quatro personagens - uma lésbica que precisa dos sofrimentos dos outros para existir, uma solteirona neurótica, a um só tempo delicada e irascível, um menino amadurecido pelo sofrimento, e uma rainha que perde a vida no plano político, mas ganha-a no plano moral e religioso - foram representadas com intensidade máxima por $\mathrm{C}$ acilda. $\mathrm{N}$ ão por conta de qualquer verossimilhança física dela com as personagens e, sim, pelo engenhoso mecanismo de burla acionado pelas convençõesteatrais, que, corporificadas numa atriz do porte de C acilda, permitia-Ihe "fazer misérias" no palco.

Como Inês, na peça de Sartre, que estreou no T BC em janeiro de 1950, C acilda não tinha, segundo D écio, "nem o físico, nem o tipo de voz ideal para o papel. $\mathrm{N}$ ão poderia, portanto, impor-se pela mera presença, por essa afinidade entre a personagem e a atriz, entre a criatura e a fiç̧ão, que significa muitas vezes metade do êxito" ${ }^{14}$ - mas que para ser completo exige maisque isso. A representação bem-sucedida implica"superar com o espírito tais dificuldades", forçando "vitoriosamente os limites da própria personalidade". Foi o que se deu com $C$ acilda. $N$ as palavras de D écio, ela ofereceu o "desempenho mais seguro da peça, extraordinário como firmeza e homogeneidade, progredindo dramaticamente do primeiro ao último minuto" (Prado, 2001, p. 247).

Poucos meses depois, em agosto de 1950, C acilda reafirmaria esse desempenho num registro mais alto. $\mathrm{N}$ o papel de AlmaW inemiller,

[...] entregue ao próprio temperamento nervoso, abandonada [numa] cidadezinha sem horizontes, entre a mãe imbecil e o pai que vive a léguas de distância, sentindo formar-se a volta de si essa simpatia humilhante que nasce da piedade e presenciando já a frustração e a neurose irem-se imprimindo lenta, seguramente, nos seus gestos tímidos e desajeitados [...] (Idem, p. 255)

ela não deixaria dúvidas sobre o quanto pode render um grande papel nas mãos, no corpo e na alma de uma grande atriz. Eletrizado, o público a assistia deixando cair "a máscara de professorinha pública, o formalismo de filha de pastor protestante, solteirona por antecipação, revelando somente 0 que havia nela de melhor - a sua feminilidade reprimida, a sua exaltada sensibilidade, a sua flama" (I dem, p. 254).

$M$ as se a todos, e a D écio especialmente, tinha parecido que a personagem AlmaW inemiller "havia marcado o ponto mais alto" da carreira de
14. Essa avaliação de D écio, escrita em 1950 e originalmente publicada em 0 Estado de S. Paulo, foi republicada junto com outras críticas feitas por ele no período no livro A pre sentação do teatro brasileiro moderno: cítica teatral de 1947-1955, cuja primeira edição, pela Livraria M artins Editora, de São Paulo, data de 1956. Em 2001, esse livro foi reeditado pela Perspectiva, com um prefácio de Sábato $M$ agaldi. 
C acilda e que, pelo menos tão cedo, "não seria possível ir mais longe", P ega-F ogo comprovou como estavam enganados" ao admitir limites para ela" . N o papel de uma criança prematuramente amadurecida pelo sofrimento, C acilda mostrou que "suas imensas possibilidades [eram] ainda mais vastas e profundas do que pensávamos". A tingindo um período de plena maturidade artística, ela começava "a elevar o nosso teatro a alturas raramente alcançadas mesmo pelo melhor teatro de outros países". Empolgado com a ascensão de $\mathrm{C}$ acilda, fruto no entender do crítico de uma mistura bem dosada de disciplina, talento, trabalho árduo e amor pela profissão, D écio oferece um quadro vívido e imagético da força da atriz.

N ão é sem emoção que há dois anos [isto é, de 1948, ano da criação e da inserção de C acilda no TBC , a 1950, data da encenação da peça] São Paulo acompanha a carreira dessa mulher, na aparência tão frágil, que se vai consumindo pelo teatro diante dos nossos olhos, emagrecendo de papel a papel, à medida que mais se afina a sua arte. C acilda vive do teatro e para o teatro, a ponto de se ter reduzido materialmente, pela sobrecarga de trabalho, pela exaustão física, a um vibrante feixe de nervos, como se a atriz dispensasse tudo que não constitua matéria para a sua arte, tudo que não seja sensibilidade nervosa (I dem, p. 262).

0 essencial dessa observação, a idéia de que a força da atriz residia num "vibrante feixe de nervos", se repetiria nas críticas subseqüentes de D écio e se tornaria uma das palavras-chave para caracterizála, quer da parte dos encenadores que a dirigiram, quer dos críticos de teatro que, na esteira deixada pelo pensamento de Décio, fizeram suas as palavras dele. Comentando a representação de Cacilda no papel da rainha escocesa, M ary Stuart, encenada pelo T BC em 1956 (na qual contracenou com a irmã, a atriz C leydeY áconis), e após passar em revista os pontos altos de sua atuação, D écio afirma que ela estava especialmente preparada para viver o drama de Schiller. "C onsagrada como a maior atriz brasileira”, ela, que era "uma atriz essencialmente moderna", deu à personagem a voltagem certa de emoções: "o pudor na emoção, o sofrimento autêntico, despido de qualquer exibicionismo". Para tanto, contou com aquilo que, na visão do crítico, mais a singularizava e destacava na cena teatral da época: não as suas qualidades físicas - relativamente minguadas quando comparadas às de outras atrizes da época, como Tônia $\mathrm{C}$ arrero e $\mathrm{M}$ aria D ella C osta, que se destacavam pela beleza, ou Dulcina de M oraes, cuja projeção de voz era bastante superior - tampouco o seu estilo, mas, fun- 


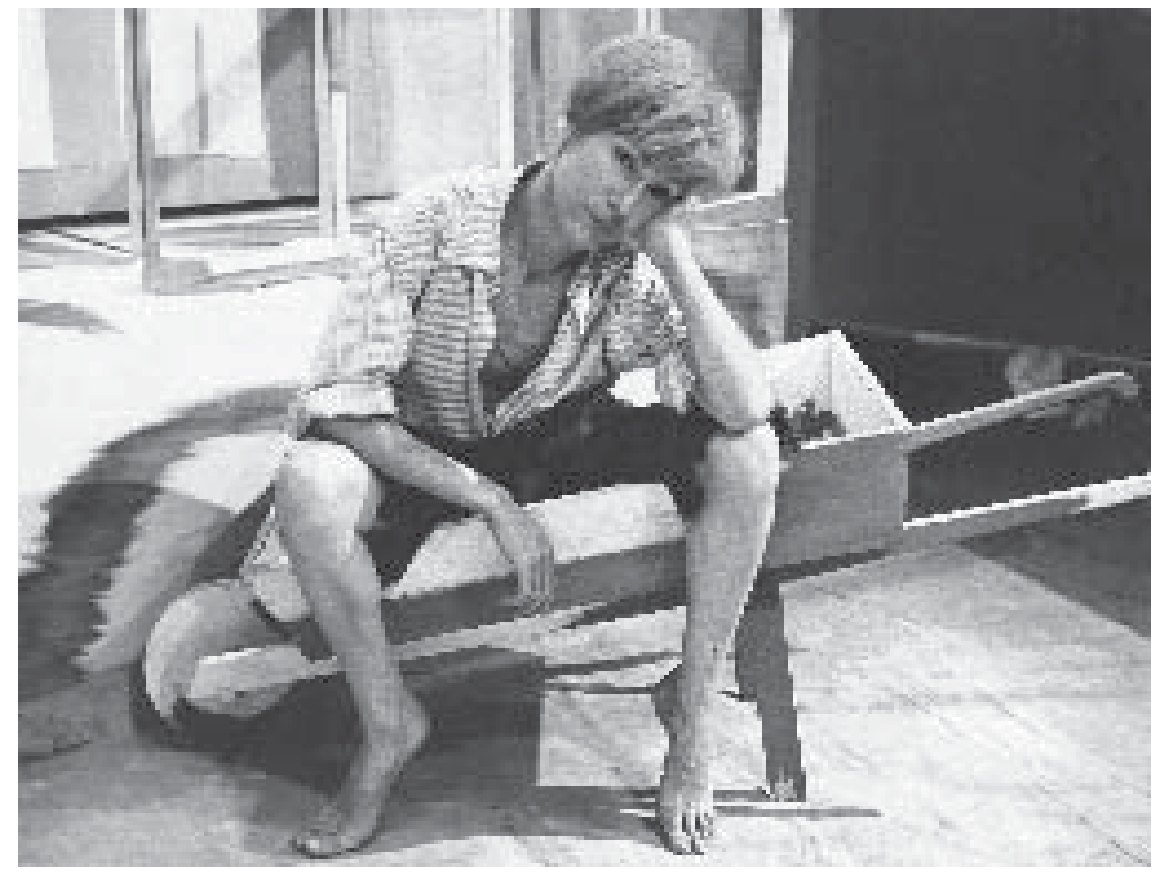

Cacilda Becker representando o menino Pega-Fogo, no TBC, dezembro de 1950. Foto cedida pela editora Geração Editorial.

damentalmente, a sua "flama interior" (Prado, 2002, pp. 4-5), nas certeiras palavras de Décio, que seriam corroboradas por todos os encenadores estrangeiros que a dirigiram no TBC.

0 italiano Ruggero Jaccobi - que chegara ao Brasil em 1946, com 26 anos - dirigiu Cacilda no teatro por três vezes (duas em 1950 e uma em 1952), mas se o seu trabal ho como diretor da atriz no teatro foi pequeno (quando comparado, por exemplo, ao de Ziembinski), na televisão ele teve um papel importante, pois a dirigiu em várias peças produzidas, ao vivo, pelo Teatro C acilda Becker para aT V R ecord de São Paulo ${ }^{15}$. N a sua avaliação, em entrevista concedida em R oma, em 1981, a singularidade de Cacilda residia em sua

[...] capacidade de tradução do papel escrito em pauta fisiológica - se é lícito dizer assim. [...] Logo que ela começava a pronunciar as palavras, deixavam de ser palavras: elas eram os fios, os feixes de fio desse sistema nervoso. $\mathrm{H}$ avia, por assim dizer, uma espécie de eletricidade na palavra e no gesto de C acilda. Ela se movia pelo palco desencadeando uma série de choqueselétricos. D iz-se comumente de uma pessoa que ela é um feixe de nervos, mas, no caso de $C$ acilda, isto tinha sido aproveitado profissionalmente. A isso veio se acrescentar a grande versatilidade,
15. Para uma análise detida da trajetória artística de Jaccobi, ver R aulino (2002). 
aquela curiosidade intelectual pela qual ela queria continuamente experimentarse em alguma coisa diferente, da tragédia à comédia de humor, do drama sentimental a certas formas de vanguarda, dos papéis de velha ao de menino - como 0 famoso Pega Fogo. N ão ficava satisfeita nunca: queria mudar continuamente e tornar cada vez mais amplo o registro do próprio repertório (apud Vargas e Fernandes, 1995, p. 137).

16. M aurice Vaneau estreou no TBC em 1956 e, desde então, radicou-se no Brasil. Assim como Jaccobi, ele dirigiu $C$ acilda, no teatro, por três vezes: umanoTBC eduasno TCB (Teatro Cacilda Becker).
Essa avaliação de Jaccobi é amplificada nas palavras do belga M aurice Vaneau $^{16}$, que a dirigiu no papel de M arta, em Q uem tem medo deV irgínia W oolf, de Edward Albee, em 1965, um dos maiores sucessos da atriz na década de 1960, quando ela já era dona de sua própria companhia. N as palavras desse diretor, Cacilda "tinha um fôlego de atriz que permitia pegar, dominar, mastigar a personagem e depois cuspi-la, ou então deixála derreter-se, projetá-la devagar ou com força, em todos os aspectos que a personagem poderia ter". Comparando-a com as grandes atrizes do mundo, Vaneau afirmou, em entrevista concedida em junho de 1981, que ela tinha um

\begin{abstract}
[...] talento de dimensão extraordinária. Q uando estava no palco, ocupava-o por inteiro, projetando para toda a platéia (não somente para as duas primeiras fileiras) todos os sentimentos que precisariam ser traduzidos a partir da personagem que estava representando [... ]. C acilda tinha esse fluído imenso, emanando ondas, circulando ondas do palco para a platéia, da platéia para o palco e vice-versa, num sistema que é básico para o teatro, porque esse fluido é capaz de tocar o intelecto, o coração, o estômago, os nervos, as artériase o sangue do espectador (apud Vargas e Fernandes, 1995, pp. 150-151).
\end{abstract}

Se todosque trabalharam com ela ou que escreveram sobre ela são unâ nimes no reconhecimento de sua capacidade extraordinária como atriz, também o são na indicação de alguns de seus atributos físicos menos bem "resolvidos" : a voz de curta extensão e de timbre ligei ramente martelado, a estranha maneira que ela tinha de acentuar aúltima sílaba de cada palavra e, principalmente, a magreza extremada para os padrões da época. C onsciente desses "defeitos" , C acilda dizia:

\footnotetext{
É sabido que tenho voz muito pequena ealgunsapontam em mim um defeito de respiração de pronúncia. R efuto o primeiro porque ele só aparece quando estou depauperada (não se trata de característica de atriz, mas da mulher que às vezes
} 
chega a pesar quarenta quilos). Q uanto à pronúncia, a minha é de fato particular, involuntariamente. Vigiando muito, o defeito se torna menor. Acentuo a última ślaba de cada palavra. M as essa é uma característica pessoal, desde criança (trecho de depoimento de C acilda Becker, cf. Vargas e Fernandes, 1995, p. 43).

Tais atributos, porém, nem de longe comprometeram a carreira da atriz. Q uando da sua morte prematura e chocante, ocorrida em 1969, como conseqüência de um derrame cerebral que a fulminou, aos 48 anos, praticamente no palco - de onde foi retirada às pressas no intervalo de $E$ sperando $G$ odot, ainda vestida com seus trajes de down -, inúmeras foram as avaliações apaixonadas que recebeu como homenagem póstuma. Pungentes em sua maioria, uma delas, em particular, condensou com economia máxima de linguagem as razões do seu magnetismo como atriz e o seu legado para o teatro brasileiro. $\mathrm{N}$ as palavras do poeta $\mathrm{C}$ arlos $\mathrm{D}$ rummond de Andrade,

A morte emendou a gramática.

M orreram C acilda Becker.

$\mathrm{N}$ ão era uma só. Era tantas [...]

$M$ ary Stuart

$M$ arta de Albee

M argarida G authier e A ImaW inemiller [...]

outras muitas, modernas e futuras,

irreveladas.

Eram também um garoto descarinhado e astuto: Pega-Fogo

E um mendigo esperando infinitamente Godot.

Era principalmente a voz de martelo sensível

$M$ artelando e doendo e descascando

a casca podre da vida

para mostrar o miolo de sombra

e a verdade de cada um nos mitos cênicos.

Era uma pessoa e um teatro.

M orreram mil C acildas em C acilda.

\section{Beleza roubada}

Se, como demonstrado acima pelo testemunho eloqüente dos que a viram representar, C acilda não foi prejudicada pelos seus atributos físicos 
17.Para uma análise abrangente da lógica que preside a organização desse ramo da indústria cultural, ver M ira (2001). menos favoráveis, isso se deve, antes de tudo, às artimanhas produzidas pelas conven ções teatrais, que, potencial izadas por uma atriz da sua estatura, permitem burlar constrangimentos de ordem variada - físicos, sociaise de gênero. Fosse outra a sua profissão - ou, na ausência de uma palavra mais precisa, o seu "talento" - e esses atributos poderiam ter sido, se não fatais, ao menos restritivos à ascensão na carreira. E aqui tocamos num ponto que me parece central para aquilatarmos dimensões menos evidentes na conformação de determinadas trajetórias femininas: a beleza ou a sua ausência. Fartamente presente na mídia para retratar, real çar ou diminuir as mulheres sob seu foco, sobretudo em se tratando de modelos, atrizes ou "políticas", a beleza raramente aparece como dimensão relevante na análise das trajetórias femininas feitas por historiadores e cientistas sociais. A não ser como referência ocasional, ligeiramente envergonhada, posto que "menor" diante de coisas "maiores" . o contrário, portanto, do que ocorre nas conversas rotinei ras de fãs, admiradores e detratores dessas carreiras femininas.

Saber se a prefeita de São Paulo, M arta Suplicy, na festa do seu segundo casamento, ocorrida em 2003, usaria ou não um modelo "leve" e "sofisticado", de tonalidade "apropriada" para "real çar" o tom da sua pele e a cor dos seus olhos, ou, para usar um exemplo mais longínquo no tempo e no espaço, se o traje sóbrio e discreto com que Eva Perón se paramentava no seu dia-a-dia de primeira-dama era simetricamente inverso ao brilho dos seus vestidos de noite, parecem ser temas adequados apenas para colunistas sociais e seus leitores - segmentados por classe, gênero e raça, nas diversas revistas que inundam as bancas de jornai $5^{17}$. $M$ as não para analistas com preocupações mais "sérias". "Fúteis" e "mundanos", esses temas nem sequer chegam a ser considerados objetos dignos de atenção, principalmente se revestidos por uma característica tão volátil e sujeita à relatividade dos padrões e dos "gostos", como a beleza. D aí serem os escritores, atentos a dimensões significativas do detal he, os mais empenhados em esmiuçar o poder da beleza e dos adereços femininos nas trajetórias de vida de suas personagens. Daí também serem poucos os ensaístas com argúcia analítica e prosa desimpedida o suficiente - como Gilda de M ello e Souza e Beatriz Sarlo - para revelar o quanto essas dimensões têm algo a dizer sobre os intricados e implacáveis jogos da interação social.

Beatriz Sarlo é autora de um ensaio notável sobre Eva Perón, "La belleza" , no qual analisa a trajetória da atriz que, não muito bem-sucedida no teatro de revista, destituída dos atributos físicos necessários para se 
ombrear às estrelas da época, tornou-se, a partir do seu casamento com Perón, uma figura central na história política da Argentina. A tenta a dimensões inesperadas e pouco usuais nas análises disponíveis sobre 0 peronismo, e em especial sobre a atuação de Eva como primeira dama, Sarlo faz um brilhante escrutínio de sua morfologia corporal, por meio da apreensão dos seus vestidos, penteados, adereços, poses, trejeitos, jóias, do tingimento dourado dos cabelos, do esmalte vermelho nas unhas, de suas fotos doente, antes de sua morte aos 33 anos, motivada pelo alastra mento do câncer. D essa visada em caleidoscópio da imagem corporal de Eva e da centralidade que a sua visualidade passara a ter no dispositivo de propaganda político do regime peronista, resulta uma das análises mais inovadoras sobre a importância do corpo real como forma visível do corpo político.

Gilda de M ello e Souza, por sua vez, em seu ensaio de sociologia estética sobre a moda no século XIX (1987), apreende-a como um objeto complexo, um "todo harmonioso maisou menos indissolúvel", com múltiplas serventias - "serve a estrutura social", "reconcilia o conflito entre o impulso individualizador de cada um de nós e o socializador", traduz uma linguagem artística, "exprime idéias e sentimentos" (1987, p. 29). N esse estudo, Gilda dá ao assunto a dimensão espiralada que Ihe é própria. $\mathrm{O}$ u seja, inicia o seu ensaio pela abordagem da moda como arte, passa pela ligação da moda com a divisão de classes, detém-se na ligação da moda com a divisão entre os sexos, revira pelo avesso a cultura feminina e fecha o livro com o "mito da borral heira". Exemplo vigoroso da profusão de acha dos analíticos que podem ser garimpados nessa sociologia da festa, o capítulo final mostra que as festas, como espaços de peneiramento e reorganização das elites, são, ao mesmo tempo, momentos privilegiados para o exercício pleno do jogo de sedução entre os sexos. N elas, os adornos, as roupas e os gestos ganham, juntamente com as maneiras e os modos dos seus portadores, significação máxima na interação social ${ }^{18}$.

Voltando a C acilda: fosse outra a época, e a sua magreza - que tanto chamou a atenção em virtude dos padrões de beleza da época (seu peso raramente atingia 47 quilos) e pelo fato de que ela parecia literalmente se consumir fisicamente no palco - seria vista com menos reserva nos anos de 1940 e 1950, e com mais adesão a partir dos anos de 1960. C omentando as razões que fizeram com que não fosse considerada uma atriz apropriada para o cinema e, em especial, os motivos da fraca repercussão de "A luz dos meus olhos", filme que fizera em 1947, C acilda pondera:
18. Para uma reflexão mais detida desse trabalho de Gilda, ver Eulálio (1987);A guiar (1999); Pontes (2004). 
Eu era muito mocinha, tinha um tipo que não era agradável ou não cabia dentro do conceito de beleza da época; era muito magra, magrinha mesmo, muito A udrey H epburn... E fui considerada, na época, pessoa não feita para o cinema, isto é, antifotogênica, de ossos expostos etc. M uitos anos depois, vendo o filme, vi 0 quanto o conceito de beleza mudara. E eu era aproveitável e poderia ter continuado [no cinema]. $\mathrm{N}$ ão continuei... (trecho do depoimento de $\mathrm{C}$ acilda Becker reproduzido em Prado, 2002, p. 226).

Emitido nos anos de 1960, esse comentário de C acilda, especialmente em sua parte final, seria assinado embaixo por Giovani M artucelli, seu cabeleireiro, amigo e um dos admiradores mais entusiastas da sua imagem corporal. Impressionado com a sua elegância - nessa época, C acilda vestia-se na C asaVogue (a mais sofisticada casa de moda de São Paulo, espécie de Daslu daquela década), prestigiava estilistas brasileiros como D enner, C lodovil e H ugo C astelana, adorava D ior e C hanel -, M artucelli ressalta que "ela tinha um corpo espetacular, era magra, tudo nela vestia bem" (apud Prado, 2002, p. 488).

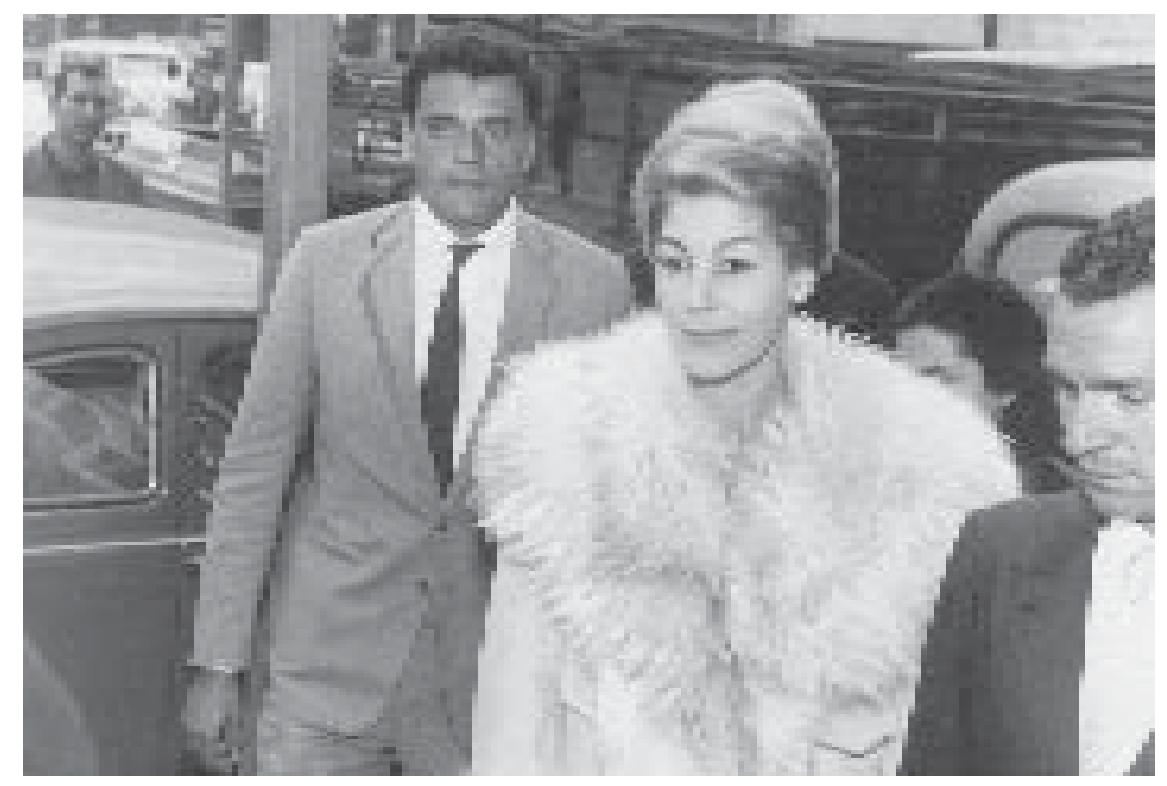

Cacilda como "mulher elegante" nos anos de 1960. Trajando Dior, ela se dirige ao Dops, acompanhada por Walmor Chagas (seu segundo marido), para prestar depoimento em sindicância que apurava a infiltração comunista no meio teatral paulista. Acervo Última Hora/Folha Imagem. Foto cedida pela editora Geração Editorial. 
V inte anos antes e a impressão causada por $C$ acilda fora completamente distinta. À magreza extremada para os padrões de beleza dos anos de 1940, associava-se a ausência de desenvoltura da atriz nos trejeitos e códigos de sociabilidade da vida mundana. $N$ em elegante, nem bonita, $C$ acilda chamou a atenção do crítico, diretor amador e um dos mais empenhados protagonistas do movimento de renovação do teatro brasileiro, Alfredo $M$ esquita, pela ausência quase absoluta desses atributos. Formado em Direito em 1932, M esquita estreou como crítico de teatro no jornal 0 E stado de S. Paulo, dirigido por seu irmão Júlio de M esquita Filho, por ocasião das temporadas de peças francesas na capital paulista entre 1936 e 1938. A partir de 1939, começou a reunir à sua volta pessoas interessadas em fazer teatro amador: as intérpretes $M$ arina Freire e I rene de B ojano, a coreógrafa C hinita U IImamm, o pintor C lóvis G raciano (que será o cenógrafo oficial do teatro amador paulista na década de 1940), 0 ator amador A bílio Pereira de A Imeida e alguns estudantes da Faculdade de Filosofia, como D écio de A Imeida Prado e Gilda de $M$ ello e Souza ${ }^{19}$. Tendo visto $C$ acilda representar pela primeira vez em 1941, na peça C oração, encenada pela companhia de $\mathrm{R}$ aul $\mathrm{R}$ oulien, Alfredo M esquita relembra a imagem confrangida da atriz iniciante na recepção que o pintor Di C avalcanti e sua mulher, N oêmia, ofereceram ao elenco da Companhia em seu "adorável duplex do Edifício Esther", localizado no centro de São Paulo.

U ns dos últimos convidados a chegar foram os "primeiros atores" da companhia, R oulien e Laura Suarez. "M as chegando", relembra A Ifredo,

[...] causaram admiração, tão bem postos estavam - ele de smoking impecável, ela de vestido de noite [...] de tafetá preto, generosamente decotado nas costas, ambos muito desenvoltos - até demais - muito à vontade, falando e rindo alto, exprimindo-se, Laura ora em português, ora em francês ou inglês, sempre porém com idêntica fluência e perfeição: 0 R oulien, para não ficar atrás, em castellano mesmo; íntimos, ambos, de todos os presentes, muitos dos quais - como eu - decerto os viam pela primeira vez. Lá atrás, visivelmente assustada, também ela de preto, a artistazinha que há pouco, no palco, chamara-me a atenção (" pela maneira simples e justa com que representava").

\section{E prossegue:}

Com a brilhante chegada dos atorese várias rodadas de whisky, a reunião animouse, subiu de tom. N um canto, só, encolhidinha, um copo de C oca-Cola a treme-
19. Ver Prado (1993a) e também o depoimento de Alfredo $\mathrm{M}$ es quita (1979). 
licar-Ihe nas mãos trêmulas, osolhões arregalados, observando espantada o carrossel que lhe ia à volta, a "segunda" ou, talvez, "terceira dama" da companhia. C omo devia sentir-se abandonada, como devia sofrer, a pobre! D ava dó. Tanto que não resisti: fui ter com ela. C umprimentei- a pela interpretação daquela noite, tentei puxar prosa, animá la. Em vão. Forçava um sorriso, que não vinha. A penas a boca repuxava-se num quase esgar, enquanto os olhos fixavam-me apavorados. Para não prolongar o martírio, achei melhor abandonar a "missão". Foi o que fiz sem Ihe ter ouvido a voz, uma pal avra sequer (M esquita, 1995, pp. 82-83).

D ois anos depois, Alfredo tornaria a ser apresentado a C acilda, desta vez por intermediação de Décio de Almeida Prado, que, como vimos, a dirigira em 1943, em A uto da barca do inferno, de Gil Vicente. Ela "vinha alegre, animada, expansiva", para espanto de Alfredo, que nesse segundo encontro viranela" a mesma mocinha modestamente vestida, de bastacabeleira alourada, magérrima, olhos negros e brilhantes", com o adendo de que, se não se tornara uma beleza, sobressaía- se agora por sua vivacidade, "um azougue, expressiva, atraente" (Idem, p. 86).

0 depoimento de Alfredo M esquita é notável pelo que diz abertamente e pelo que sugere nas entrelinhas. Como membro da poderosa família M esquita, dona de 0 E stado de S. Paulo,A Ifredo fora socializado no universo da elite paulista e tinha de sobra o que se pode chamar de savoir faire, ou, para usar uma terminologia sociológica, o seu habitus, internalizado sob a forma de disposições corporais e esquemas de avaliação e percepção. À frente de vários projetos de ressonância no âmbito da cultura paulista, como a revista C lima, o G rupo Experimental de Teatro e a Escola de Arte D ramática (criada por ele em 1948), Alfredo pôde, em função do capital social, cultural e econômico acumulado por sua família, dar vazão aos assuntos de sua predileção: a cultura em sentido amplo e o teatro em particular. N esse domínio, partilhou a companhia de atores e atrizes, incentivou suas carreiras, contribuiu com a sua presença e com a sua escola para a formação e a profissionalização de vários deles. A distância social, no entanto, por mais proximidade e afinidade que pudessem ter no plano da cultura, era intransponível, como atestam de maneira inequívoca as suas primei ras lembranças de $\mathrm{C}$ acilda.

Se, com o tempo, ele engrossaria a legião de admiradores da atriz, tornando-se seu amigo e padrinho do seu único filho, Cuca (Luis C arlos Fleury, nascido do primeiro casamento da atriz com T ito Fleury), é certo também que soube "pinçar" sem meias palavras, e com aquela condescen- 
dência própria dos muito seguros socialmente, as "fragilidades" iniciais de C acilda, antes de ela se celebrizar como a "primeira atriz" do TBC, nos anos de 1950, e virar a" mulher elegante" da década de 1960. Q uais sejam: afalta de" beleza" e de "traquejo" social. C ada uma em separado, tal vez não chamassem tanto a atenção de A Ifredo. Pois se atrizes como Laura Suarez (uma das vedetes da época) e B ibi Ferreira podiam transitar com facilidade do português para o francês e deste para o inglês, o mesmo não se pode dizer da mai oria das atrizes profissionais da época, que, diferentemente das amadoras, vinham de famílias humildes ou de classe média baixa, muitas delas ligadas ao teatro de revista ou mambembe, com precária formação escolar. M as se a origem era "baixa", as "maiores" podiam "compensar" essa "falta" com algum trunfo físico particular, como a beleza no caso de T ônia C arrero e especialmente de M aria D ella C osta.

Tendo inicialmente de vencer a pobreza, e suas conseqüências, $M$ aria D ella C osta educou-se, aprendeu "a exprimir-se, a vestir-se, a pensar e a ter personalidade". M asisso, na visão de D écio deA Imeida Prado, foi o de menos.

O obstáculo maior para chegar onde chegou era natural mente a sua beleza, que a marcava entre as outras mulheres, abrindo- Ihe uma série de carreiras fáceis, capazes de deslumbrar qualquer jovem. M aria D ella C osta foi girl, exibiu-se nos cassinos, passou pelas casas de moda, como "modelo", e de toda essa experiência trouxe o hábito do trabalho, a consciência profissional, a ambição de ser uma grande atriz [...]. Sem qualquer cultura literária especial (não houve tempo para isso) preferiu sempre, instintivamente, o bom teatro, com essa humildade perante a arte que é a sua melhor qualidade e a mais rara numa mulher bonita. Estudou, submeteu-se, voluntariamente, assim que pôde, à disciplina de um encenador, fazendo questão de criar uma companhia baseada não na exaltação de sua pessoa, mas no valor do conjunto (Prado, 2001, p. 228, grifos meus).

O comentário de D écio é parte de uma crítica maior que ele escreveu em 1955, quando da estréia do Teatro $M$ aria D ella C osta, feita com a peça 0 canto da cotovia, de Jean A nouilh, na direção impecável do cenógrafo e diretor Gianni R atto. A bordando de passagem a trajetória e a carreira da "primeira atriz" da companhia, Décio toca numa questão essencial: 0 lugar paradoxal que a beleza tem no universo do teatro. Espécie de "abrete Sésamo" em profissões como as de modelo, quase essencial para o deslanchar de uma carreira no cinema, a beleza, para as atrizes de teatro, pode 
ser, como bem frisou Décio, um obstáculo a superar. M arca poderosa, se "colada" demais à figura da atriz a beleza pode ser um empecilho para que ela leve adiante 0 trabalho de burla propiciado e exigido pelas convenções teatrais, impedindo, assim, que encene corporalmente a plêiade de personagens disponíveis na dramaturgia teatral.

$\mathrm{N}$ ão sendo bonita como M aria D ella C osta - com seusolhosazuis, nariz afilado, abundantes cabelos louros, alta e elegante, espécie de $\mathrm{C}$ atherine D eneuve local -, C acilda partilhava com ela uma origem social das mais humildes. $\mathrm{N}$ o seu caso, mais humilde que a dela. Q uando $\mathrm{C}$ acilda nasceu, em 1921, os pais moravam num sítio em Pirassununga, numa casa de paua- pique sem água encanada (cf. Prado, 2002, p. 35). A os seis anos, ela e suas duas irmãs maisnovas, C leyde e D irce, mudaram- se para São Paulo, com a mãe Alzira Becker (filha de imigrantes alemães protestantes que para cá vieram em 1860) e o pai Edmundo RadamésYacónis (descendente de gregos e italianos calabreses que imigraram para o B rasil em 1880). M oraram um ano num bairro de periferia. 0 pai passava a maior parte do tempo longe das filhas e da mulher, que praticamente tinha de sustentá-las

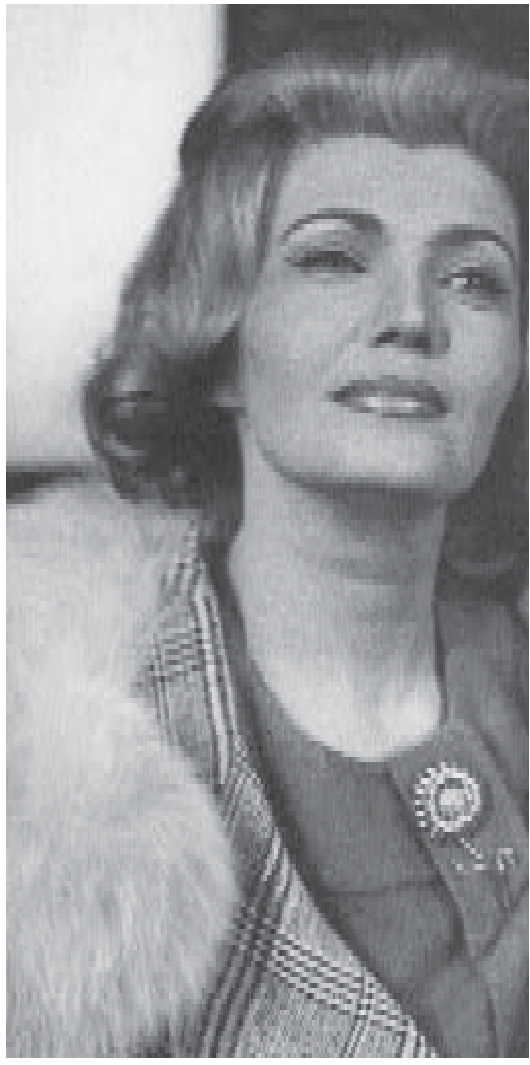

Maria Della Costa, reconhecidamente uma das mulheres mais bonitas do teatro brasileiro. Nessa foto ela lembra (e muito) a atriz francesa Catherine Deneuve. Foto tirada em 1961, na peça Armadilha para um homem só. Arquivo do Estado/ Centro de Memória do Teatro Paulista. Foto reproduzida na revista Cultural, abril de 2002. 
sozinha. Sem a proteção da família extensa, que ficara em Pirassununga - e lá vivia em situação de extrema pobreza, enfrentando os"vícios da pobreza" e as necessidades superadas "à custa de dolorosas e vergonhosas humiIhações" - , C acilda, a mãe e as irmãs atravessaram um dos períodos mais difíceis de suas vidas. $\mathrm{N}$ as palavras da atriz, "até passamosfome. Fui obriga da um dia a roubar um pé de verdura para o al moço. $M$ achuquei o pée tive tétano. R oubar, acho que não foi importante: a fome é que me dói até hoje" (trecho de depoimento de C acilda Becker, cf. Vargas e Fernandes, 1995, p. 24).

A relação dos pais, que já era ruim, tornou-se insustentável nesse período, culminando com a separação, em 1929, e a volta de Alzira e suas três filhas para a casa dos avós maternos em Pirassununga. Pouco tempo depois, com o novo emprego da mãe, que se tornara professora primária numa escola rural localizada numa fazenda a sessenta quilômetros de Pirassununga (e cujos trabal hadores eram, em sua maioria, imigrantes japoneses ou descendentes), C acilda tomou para si a tarefa de "substituir" 0 pai. A decisão, acalentada no ano "mais amargo e marcante" da sua vida, foi tomada numa noite de insônia, quando teve a clara noção de que "virara gente". T inha então nove anos. A partir daí passou a "agir como um pai" e "obrigou" a mãe a deixar a fazenda e ir para Santos, para que ela e as irmãs pudessem estudar. Em suas palavras, "nós éramos três meninas. Lindas, inteligentes, sensíveis, precoces, com mamãe. A bandonadas pelo papai. Praticamente sozinhas no mundo. E a vida foi dura" (Idem, p. 28).

Em Santos, moravam em um chalé de madeira alugado. Dos três cômodos, um foi transformado em sala cozinha. 0 banheiro ficava do lado de fora da casa, no chuveiro apenas água fria. A mobília era improvisada com caixotes pintados. Graças ao trabalho da mãe como professora primária, puderam voltar à escola e concluí-la sem as interrupções freqüentes de antes. 0 s uniformes eram costurados à mão, reaproveitando roupas usadas, os cadernos escolares, confeccionados com folhas de papel de embrulho (cf. Prado, pp. 75-77). Sapatos eram artigo de luxo. C acilda tinha 14 anos quando usou o primeiro par.

Entende-se, assim, que ela não tivesse saudades da adolescência. 0 que não quer dizer que fosse infeliz. Pois se a pobreza era muita e o conforto quase nenhum, ela e as irmãs tinham, em "compensação", uma liberdade de movimentos maior que a habitual na época para as moças solteiras. C acilda, que adorava dançar, experimentou-se como dançarina moderna e amadora, travando contatos e amizades interessantes, como a de Flávio 
de C arvalho (que por ela se enamorou) e de M iroel Silveira, que, além de Ihe franquear 0 acesso à intelectualidade e aos artistas de Santos que freqüentavam a casa de seus pais, foi o maior responsável pela inserção de $C$ acilda no mundo do teatro.Vendo que a vontade dela de se tornar dançarina profissional tinha poucas chances de se concretizar, e estando a par das transformações em curso no teatro carioca, M iroel escreveu para a encenadora $\mathrm{M}$ aria Jacintha indicando $\mathrm{C}$ acilda, que a aproveitou na peça que o Teatro do Estudante estava em vias de montar:3200 metros de altura, apresentada em 1941. N ela e no papel de Zizi, como vimos, C acilda fez a sua estréia no teatro.

M as se a dança acabou se revelando um devaneio de adolescência, ela foi, no entanto, mais que uma das grandes paixões de C acilda. PermitiuIhe a primeira incursão em um círculo com interesses culturais e intelectuais e, ao mesmo tempo, propiciou uma fonte de sustento indireto para a família. A o completar o primeiro ano do ginásio, $C$ acilda foi convidada por uma de suas professoras para dançar na festa de final de ano do colégio particular onde estudava. Terminado o espetáculo, a diretora a procurou para, além de parabenizá la, oferecer a ela e às duas irmãs (que não estudavam ali, em razão das dificuldades financei ras da mãe, que as mantinha na escola pública) o acesso gratuito ao restante do ginásio e ao curso normal. Ajuda essencial para que pudessem prosseguir os estudos e, no caso de C acilda, se formasse em 1940 como normalista, seu último grau na escolarização formal. A universidade estava excluída do seu horizonte de possibilidades.

Se a inserção na vida profissional do teatro permitiu- Ihe uma profusão de conquistas importantes, nem por isso apagou as marcas doídas da po-

20. Interessante notar que $C$ acilda adota 0 sobrenome materno, Becker, excluindo 0 paterno, e sua irmã Cleyde, ao se lançar como atriz, opta por usar apenaso sobrenome do pai, Yáconis. breza e o sentimento de humilhação que experimentara até então. 0 "nome próprio" 20, a formação cultural que não tivera na infância e na adolescência, 0 acesso a círculos de sociabilidade impensáveis para al guém de sua origem social, a aquisição de uma série de bens materiais e simbólicos, a vivência de relações amorosas marcantes (com Tito Fleury, seu primeiro marido e, por um tempo, ator profissional, com o diretor italiano Adolfo Celi e, por fim, com o ator e diretor Walmor Chagas, com quem fundaria a sua própria companhia, o Teatro $C$ acilda Becker, ao sair do TBC, em 1957) e, sobretudo, a chancela de maior atriz do período foram essenciais para o equacionamento da imagem pública e da autoimagem da atriz. $M$ as não para o esfacelamento dos sentimentos mais sofridos e tumultuados advindos da vivência aguda da pobreza, os quais se 
entranhavam nela sob uma forma distinta da héxis corporal exibida pelos socialmente excluídos. $\mathrm{N}$ o caso de $\mathrm{C}$ acilda, com a soberania e a desenvoltura próprias das grandes atrizes, que, sujeitando seus corpos ao trabal ho de suporte de experiências alheias, por vezes bastante longínquas de suas vivências pessoais e familiares, dominam as convenções teatrais a ponto de infundir aos sentimentos uma pletora de significados novos e inespera dos. N ão só por um ato de vontade intelectual, mas, principalmente, pelo que conseguem fazer corporalmente com eles. N essa "incorporação" da experiência alheia, burlam convenções sociais de classe, de gênero e de idade, imprimindo às personagens que representam verossimilhança e verdade renovadas com aquela voltagem el etrizante, os tais" feixes de nervos", que o público sabe reconhecer, quando é fisgado pelo desempenho delas no palco, embora só alguns, como Décio de Almeida Prado, sejam capazes de traduzir com tanta precisão em palavras.

$\mathrm{N}$ em bonita nem bem formada, em razão da sua origem social e da sua precária escolarização, "marcada" para sempre, em suas palavras, "pela pobreza", C acilda triunfou porque elevou a alturas máximas a sua competência como atriz, em um contexto muito particular de renovação do teatro brasileiro. Contando com a experiência acumulada dos diretores estrangeiros - que para cá vieram em decorrência de perseguições étnicas acentuadas durante a Segunda Guerra, como Ziembienski, ou de condições pouco animadoras de trabalho no pós-guerra, como no caso dos italianos que passaram pelo TBC, Adolfo C eli, Ruggero Jacobbi, Gianni R atto ${ }^{21}$ - , C acilda pôde suprir as deficiências de sua formação, driblar seus atributos físicos menos favoráveis, familiarizar-se e dominar as técnicas e as convenções teatrais que fizeram do TBC o modelo por excelência do teatro brasileiro até meados dos anos de 1950. A creditando totalmente no trabalho de direção, aprendeu com os diretores estrangeiros uma maneira nova de representar, distinta daquela que, segundo A dolfo C eli, advinha de "uma descendência portuguesa do velho teatro, que correspondia a uma velha maneira de representar na Itália" (trecho de depoimento de C eli, cf. Vargas e Fernandes, 1995, p. 124). D isposto "a acabar" com essa tradição, C eli, ao ser contratado pelo T BC em 1949, encontrou em $\mathrm{C}$ acilda a atriz ideal para levar adiante $\mathrm{O}$ seu projeto de renovação teatral. Profissional impecável, pontual, disciplinada, ela era a primeira a chegar e a última a sair do teatro. Entregava-se "total mente ao papel" que estava fazendo e "amava repetir" suas falas até a "exaustão" (Idem, p. 121).
21. Sobre a atuação desses diretores, ver Guzik (1986, 1998,); Almeida (1987); D ionysos, 25 (1980); Prado (1988); Raulino (2002).Ver também os depoimentosdeA dolfo C eli, R uggero Jacobbi e G ianni R ato em Vargase Fernandes(1995), bem como as memórias de Gianni Ratto (1996). 
22. Trecho do depoimento de Ziembinski apresentado no programa" H omenagem a C acilda, R ádio,Televisão e Cultura", C anal 2,em 6 de abril de 1979 e reproduzido em Vargase Fernandes (1995).

23. Seriainteressantefa zer um paralelo entre a origem social, 0 inves timento na carreira e a centralidade que $\mathrm{C}$ acilda e Florestan Fernandes adquiriram nosseus respectivos campos de atuação (o teatro e a sociologia) em função das transformações mais amplas que estavam se produzindo no sistema cultural paulista. Ambos foram marcados pela experiência funda e doída da pobreza esouberam reconvertê la em um instrumento poderoso de análise, no caso de Florestan, e de chave interpretativa, no deC acilda Por hora, deixo indicado o que será objeto de um artigo futuro.
$\mathrm{N}$ as palavras de Ziembinski, 0 diretor com quem mais trabalhou ao longo de sua carreira (ao todo, ele a dirigiu em dez peças, quatro no T BC e seisno T C $B$ ), um dosslogans de $C$ acilda, quando Ihe propunha um novo espetáculo, era: "Vamos trabalhar!Vamos ter um trabalho infernal!" . Para ela, prossegue Ziembinski, "trabal ho infernal era fonte de alegria, de necessidade de esforço extremo. $\mathrm{N}$ o calor do trabal ho, da luta para conquistar novos valores, ela se sentia renascer, ao mesmo tempo em que o corpo frágil se transformava em corpo de gigante, um corpo iluminado" (Idem, p. 142)22. 0 qual, como vimos, permitial Ihe transitar por personagens muito distintas, da rainha $M$ ary Stuart ao menino Pega-Fogo. $N$ ão só em virtude dos aparatos externos que ela mobilizava para dar verossimilhança às personagens encenadas - 0 traje majestoso com que se paramentava de rainha ou o esparadrapo com que apertava os seios debaixo da camisa, para tornar mais crível a sua representação de menino -, mas sobretudo pela capacidade de converter a experiência de humilhação e privação da infância e da adolescência em uma poderosa chave interpretativa ${ }^{23}$ - como bem souberam reconhecer as pessoas que Ihe eram mais próximas, por estarem inteiramente imersas, como ela, no mundo do teatro, na condição de atores, diretores ou críticos.

Comentando o desempenho de Cacilda em Pega-Fogo, A dolfo Celi ressalta que foi "a coisa mais bonita que vi dela. Foi uma coisa extraordinária [...]. Ela conseguiu mostrar toda a sua infância, uma infância que não deve ter sido fácil. Ela conseguiu transmitir toda essa dor, a dor de uma criança que não foi feliz, que nunca foi feliz" (I dem, p. 120). Avaliação corroborada também pelo crítico e historiador do teatro brasileiro Sábato $M$ agaldi, que, desconcertado com a constatação de que os dois papéis de sua predileção na carreira da atriz eram masculinos (Pega-Fogo e Estragon, em E sperando $G$ odot), escarafuncha o significado dessa coincidência. A seu ver, ela advinha não do fato de que $C$ acilda "aparentasse masculinidade em cena" . A o contrário, "ela era bem feminina, em tantas criações". Sua fragilidade pessoal, pondera Sábato, "é que emprestava a Pega Fogo e a Estragon o corte profundamente humano. D esamparo, tristeza, perplexidade diante da vida, sofrimento contido, humilhação - eram a matériaprima que vinha das raízes da infância e se colava às personagens, fazendo-as tão autênticas" (M agaldi, 1995, p. 19).

M asculinos, esses dois papéis são a expressão contundente do quanto 0 "nome próprio" se associa, no caso das grandes atrizes - como a italiana Eleonora D use, a russa Ludmilla Pittöeff, as brasileiras Fernanda M onte- 
negro e Cacilda Becker -, à corporificação dos mecanismos de burla produzidos pelas convenções teatrais. Fazendo do corpo o seu suporte mais importante, 0 teatro permite às grandes atrizes contornar os impera tivosimplacáveis da beleza e do envelhecimento. 0 que dificilmente ocorre em outros domínios onde o corpo é também central, como a dança, 0 cinema e a moda. Paradoxo interessante, o caso do teatro e das atrizes dá o que pensar, como procurei mostrar ao longo desse artigo.

\section{Referências Bibliográficas}

A guiAR, Joaquim Alves de. (1999), "A notações à margem de um belo livro". L iteratura e Sociedade, 4: 129-140.

A Lm EIDA, M aria Inês Barros de. (1987), Panorama visto do R io: C ompanhiaTonia-C eliA utran. $\mathrm{R}$ io de Janeiro, Inacen.

ArRuda, M aria Arminda do N ascimento. (2001), M etrópole e altura. Bauru, Edusc. BAXAN DALL, M ichael. (1991), 0 olhar renascente: pintura e experiência social na $R$ enascença. Rio de Janeiro, Paz eTerra.

Bender, Thomas. (1987), N ew York intellect. N ovaYork, Knopf.

BERnst Eln, Ana. (1995), A óitica aúmplice. Dissertação de mestrado. R io de Janeiro, PU C. Bour dieu, Pierre. (1984), H omo academicus. Paris, M inuit. . (1996a), "O s ritos de instituição". In: A economia das trocas lingüísticas. São Paulo, Edusp. . (1996b), As regras da arte. São Paulo, Cia. das Letras. \& Delsaut, Y vette. (1975), "Le couturier et sa griffe: contribuition à une théorie de la magie". A ctes de la R echerce en Sciences Sociales, 1: 7-36.

Brandão, Tânia. (2002), Teatro dos Sete: a máquina de repetir e a fábrica de estrelas. R io de Janeiro, 7 Letras.

CASTRO, R uy. (1992), 0 anjo pornográfico: a vida de N elson R odrigues. São Paulo, Cia. das Letras.

C LARCK, T. J. (1986), T he painting of modern life. Princeton, Princeton U niversity Press. C ORREAA, M ariza. (1995), "A natureza imaginária do gênero na história da antropologia". C adernos Pagu, 5.

. (2003), A ntropólogas e antropologia. Belo H orizonte, Editora da U FM G.

D EBERT, Guita Grin. (1999), A reinvenção da velhice. São Paulo, Edusp.

D Ionysos (1975). R io de Janeiro, M ec-Funarte, 22, dez.

D Io y y sos (1980).A lberto Guzik e M aria Lúcia Pereira (orgs.). R io de Janeiro, M ecFunarte, 25, set. (número especial sobre o Teatro Brasileiro de Comédia).

ELIAS, N orbert. (1985), La socééé de cour. Paris, Flammarion. 
. (1995), M oz art: sociologia de um gênio. R io de Janeiro, Zahar.

Eu lálıo,Alexandre. (1987), “Pano para manga” (Prefácio). In: M ello e So uzA, Gilda.

0 espírito das roupas: a moda no século XIX, São Paulo, C ia. das Letras.

FARIA, João R oberto; ÂreAs, Vilma \& A guIAR , Flávio. (1997), D édo deA Imeida P rado: um homem de teatro. São Paulo, Edusp.

Fernandes, Florestan. (1970), A função sodal da guerra na sodiedadeTupinambá. 2. ed. São Paulo, Edusp/ Pioneira.

Galvão, M aria Rita. (1981), B urguesia e ánema: o caso Vera C ruz. R io de Janeiro, Civilização Brasileira.

Ginzbur G, C arlo. (1989), “D eWarburg a E. H. Gombrich”. In: . M itos, emblemas e sinais, São Paulo, $\mathrm{C}$ ia. das Letras.

Gluck, M ary. (1985), G eorg L ukács and his generation. Cambridge, M assachusetts, $\mathrm{H}$ arvard U niversity Press.

Guzık, A lberto. (1986), T BC : cônicas de um sonho. São Paulo, Perspectiva. . (1998), Paulo A utran: um homem no palc. São Paulo, Boitempo.

Jouvet, Louis; D uluın , C harles; Pito ËFf, George \& Baty, Gaston. (1997), “M anifesto de fundação do C artel" (6 jul. 1927). In: D u sIGN E, Jean-François. L e théâtre d'art: aventure européene du XX è siéde, Paris, Théâtrales.

LeSSA, D avid José. (2002), 0 espetáculo da cultura paulista: teatro e televisão em São Paulo (décadas de 1940 e 1950). São Paulo, Códex.

M AGALDI, Sábato. (1987), N elson R odrigues: dramaturgia e encenações. São Paulo, Pers pectiva/ Edusp. . (1995), “À maneira de prefácio e depoimento". In: VAR GAS, M ariaT hereza \& Fernandes, N anci (orgs.). U ma atriz: C aálda Becker. 2. ed. revista, São Paulo, Perspectiva (1. ed. 1983).

. (2001), "C onsciência privilegiada do teatro" In: Prado, D écio de Almeida.

A presentação do teatro moderno brasileiro, São Paulo, Perspectiva, pp. ix-Xv.

M Ay buRY - Lewis, D avid. (1984), A sodedade X avante. R io de Janeiro, Francisco Alves. M ello E So uzA, Gilda. (1987), 0 espírito das roupas: a moda no séaulo X IX. São Paulo, Cia. das Letras.

M esquita, A lfredo. (1979), “N o tempo do Jaraguá” . In: LAfer , C elso (org.). E sboço de figura: homenagem a A ntonio $C$ andido, São Paulo, D uas Cidades. . (1995), "De como vim a conhecer C acilda Becker e o que se seguiu”. In: VAR GAS, M ariaT hereza \& FER n An Des, $N$ anci (orgs.). $U$ ma atriz : $C$ adilda B ecker. 2. ed. revista, São Paulo, Perspectiva (1. ed. 1983).

M IC ELI, Sergio. (1997), Imagens negociadas. São Paulo, C ia. das Letras. M ICHASKI,Yan. (1995), Z iembinski e o teatro brasileiro. São Paulo/ R io de Janeiro, H ucitec/ Mec-Funarte. 
M IRA, M aria C eleste. (2001), 0 leitor e a banca de revistas. São Paulo, O lho d'Á gua/ Fapesp.

Pallotin I, R enata. (1995), C adilda B ecker: 0 teatro e suas chamas. São Paulo, Arte \& Ciências.

Pontes, H eloisa. (1998), D estinos mistos: os críticos do G rupo C lima em São Paulo, 1940 -

1968. São Paulo, C ia. das Letras.

. (2000), "Louis Jouvet e o nascimento da crítica e do teatro modernos no Brasil". N ovos E studos C ebrap, 58, nov.

. (2003), "Cidades e intelectuais: os 'nova-iorquinos' da Partisan R eview e os

"paulistas' de C lima entre 1930 e 1950" . R evista B rasileira de C iêndias Sodais, 53, out. . (2004), "M odas e modos: uma análise enviesada de '0 espírito das roupas". C adernos Pagu, 22.

Prado, Luis André. (2002), C aćlda B ecker: fúria santa. São Paulo, Geração Editorial.

Pr Ado, D écio de A Imeida. (1969), “A deus a C acilda” . 0 E stado de S. Paulo, 15 jun. . (1988), 0 teatro brasileiro moderno. São Paulo, Perspectiva.

. (1993a), "Alfredo M esquita, visto de um ângulo só". In: Peças, pessoas

e personagens, São Paulo, Cia. das Letras.

. (1993b), “C acilda, paixão e morte”. In: . P eças, pessoas e personagens, São

Paulo, Cia. das Letras.

. (1993c), Peças, pessoas, personagens. São Paulo, Cia. das Letras.

. (2001), A presentação do teatro moderno brasileiro. São Paulo, Perspectiva (1. ed. 1956).

. (2002), Teatro em progresso: cítica teatral (1955-64). 2. ed. São Paulo, Perspectiva (introdução de João R oberto Faria) (1. ed. 1964).

R Aтto, Gianni. (1996), A mochila do mascate. São Paulo, H ucitec.

R au lino, Berenice. (2002), R uggero Jacobbi: presença italiana no teatro brasileiro. São Paulo, Perspectiva/ Fapesp.

R o sen feld, A natol. (1993), Prismas do teatro. São Paulo, Perspectiva/ Edusp/ Editora da U nicamp.

R o SSELLI, John. (1992), Singers of I talian opera: the history of a profession. C ambridge, C ambridge U niversity Press.

Sarlo, Beatriz. (2003), La pasión y la excepcón. BuenosAires, Siglo 21.

Schorske, C arl. (1993), V iena fin-de-siède. São Paulo, Cia. das Letras.

Simıon I, Ana Paula. (2002), "Entre convenções e discretas ousadias: Georgina de A lbuquerque e a pintura histórica feminina no Brasil". R evista B rasileira de C iêndas Sodais, 17 (50), out.

Vargas, M ariaT hereza \& Fer n an des, $N$ anci (orgs.). (1995), U ma atriz : C acilda B ecker.

2. ed. revista. São Paulo, Perspectiva (1. ed. 1983). 
Viveiros de CAstro, Eduardo. (1986), A rawaté: os deuses canibais. Rio de Janeiro, Zahar.

W ILLIAMS, R aymond. (1982), "The Bloomsbury fraction". In: . Problems in materialism and culture. Londres, Verso Editions. . (1989), 0 campo e a didade. São Paulo, Cia. das Letras.

\section{Resumo}

0 artigo procura explicar as razões que levaram as atrizes brasileiras a conquistarem mais cedo do que em outros campos da produção cultural o "nome próprio" e tudo que dele decorre - notoriedade, prestígio e autoridade. Esse pressuposto é desenvolvido por meio do esquadrinhamento da morfologia corporal e da carrei ra fulgurante de C acilda Becker (1921-1969).Transitando por personagens muito distintas, da rainha M ary Stuart ao menino Pega-Fogo, $\mathrm{C}$ acilda triunfou porque elevou a alturas máximas a sua competência como atriz, em um contexto muito particular de renovação do teatro brasileiro. $\mathrm{N}$ em bonita nem bem formada, em razão de sua origem social e da sua precária escolarização, marcada para sempre, e em suas palavras, "pela pobreza" , C acilda pertence ao time seleto das grandes atrizes que, fazendo de seus corposo suporte privilegiado para a reconversão de experiências alheias, dominam as convenções teatrais a ponto de burlar constrangimentos sociais de classe, de gênero e de idade, infundindo às personagens uma pletora de significados novos e inesperados. Entender como isso aconteceu com Cacilda é o objetivo central do artigo. Palavras-chave: C acilda Becker; D écio de Almeida Prado; Teatro brasileiro moderno; A trizes; G ênero; N ome e renome.

H eloisa Pontes é professora do Departamento de Antropologia da U nicamp e pesquisadora do Pagu, Núcleo de Estudos de Gênero. 